\title{
A quadruplex real-time PCR assay for rapid detection and differentiation of the Clostridium botulinum toxin genes $A, B, E$ and $F$
}

\begin{abstract}
Correspondence
Richard A. Robison

richard_robison@byu.edu
\end{abstract}

Received 1 May 2009

Accepted 22 September 2009

\author{
Benjamin A. Satterfield, ${ }^{1}$ Alvin F. Stewart, ${ }^{1}$ Cynthia S. Lew, ${ }^{1}$ \\ David O. Pickett, ${ }^{1}$ Marissa N. Cohen, ${ }^{1}$ Emily A. Moore, ${ }^{1}$ \\ Patrick F. Luedtke, ${ }^{2}$ Kim L. O'Neill ${ }^{1}$ and Richard A. Robison ${ }^{1}$
${ }^{1}$ Department of Microbiology and Molecular Biology, Brigham Young University, Provo, UT 84602, USA
${ }^{2}$ Utah Department of Health, Salt Lake City, UT 84013, USA

Clostridium botulinum is the aetiological agent of botulism, a disease marked by flaccid paralysis that can progress to asphyxiation and death. This species is defined by the production of one of the botulinum neurotoxins (BoNTs), which are the most potent toxins known. Because of their potency, these toxins have the potential to be used as biological weapons, and therefore $C$. botulinum has been classified as a category $A$ select agent. There are four related but antigenically distinct BoNT types that cause disease in humans, A, B, E and F. The mouse bioassay is the current gold standard by which BoNTs are confirmed. However, this method is expensive, slow and labour-intensive. Although PCR-based assays have been used extensively for the detection of BoNT-producing bacteria in food, animals and faecal samples, and recently to help diagnose disease in humans, no real-time quantitative PCR (qPCR) assay has yet been developed that can identify and differentiate all four BoNTs that cause disease in humans. This report describes the development of a qPCR single-tube assay that uniquely identifies these four BoNTs responsible for human disease. A total of $79 \mathrm{C}$. botulinum isolates with varying toxin types was evaluated in this study, as well as numerous near-neighbours and other bacterial species. The results showed that this quadruplex assay was capable of detecting any of the four toxin genes in a given sample at a sensitivity of about $130-840 \mathrm{fg}$ genomic DNA and could detect the presence of up to all four BoNT genes simultaneously in a given sample. The assay was also functional in the presence of extraneous organic matter commonly found in various environmental samples.

\section{INTRODUCTION}

Clostridium botulinum is a spore-forming, Gram-positive bacterium that produces the most potent toxins known, with an $\mathrm{LD}_{50}$ in primates of $1-10 \mathrm{ng}(\mathrm{kg} \text { body weight })^{-1}$ (Franz et al., 1997). Due to their potency, botulinum neurotoxins (BoNTs) have the potential to be used as biological weapons. Therefore, C. botulinum has been classified as a category A select agent by the Centers for Disease Control and Protection (CDC). BoNTs can enter the body via three different routes: inhalation, ingestion and absorption from wound infections. Ingestion of $C$. botulinum spores by infants has been associated with sudden infant death syndrome (Bartram \& Singer, 2004; Smith \& Sugiyama, 1988). Once vegetative cells are lysed,

Abbreviations: BoNT, botulinum neurotoxin; qPCR, real-time quantitative PCR.

Details of qPCR results for individual bacterial isolates are available as supplementary material with the online version of this paper. the toxin is released (Franz et al., 1997) and, upon entering a mammalian host, the toxin is taken up by lower motor neurons at the neuromuscular junction. The toxin acts to block acetylcholine release by cleaving the SNARE proteins, thus blocking neurotransmitter exocytosis. This creates a state of flaccid paralysis in the affected individual that steadily increases until asphyxiation and death. This paralytic disease state is known as botulism.

The defining characteristic of the genetically diverse $C$. botulinum species is the production of one or more of the seven antigenically distinct BoNTs A-G (Collins \& East, 1998; Hatheway, 1990; Lindström et al., 2001). Human botulism is caused typically by toxin types A, B, E and occasionally F. BoNT genes from numerous strains of types $\mathrm{A}, \mathrm{B}, \mathrm{E}$ and $\mathrm{F}$ have been sequenced and show 2.6-31.6\% sequence variation within each serotype (Smith et al., 2005). This has led to the identification of various subtypes within each toxin type: five distinct subtypes within the BoNT A serotype (Carter et al., 2009), four or five subtypes 
within the BoNT B serotypes (Hill et al., 2007; Smith et al., 2007), six distinct subtypes of serotype $\mathrm{E}$ strains (Chen et al., 2007) and three subtypes of BoNT F (Smith et al., 2005).

The detection and identification of C. botulinum is useful to researchers, food processors and healthcare professionals. The mouse bioassay is the current gold standard by which BoNT type is confirmed. However, this method is expensive, slow and labour-intensive, taking up to 4 days to complete. In addition, this assay carries ethical concerns due to the need to sacrifice mice. Commercial biochemical tests have failed in identifying various toxin-producing strains of C. botulinum (Lindström et al., 1999). PCR-based assays have been used extensively for detection of BoNTs in food, animals and faecal samples (Aranda et al., 1997; Braconnier et al., 2001; Dietmaier \& Hofstadter, 2001; Fach et al., 1993, 1995, 2002; Franciosa et al., 1994; Lindström et al., 2001; Takeshi et al., 1996). Traditional PCR methods using agarose gel electrophoresis for the characterization of amplification products can be used (Szabo et al., 1993), but require more time to perform because of the added step of gel electrophoresis, and identification is based solely on the size of the amplicons, which may be misleading. Real-time quantitative PCR (qPCR) overcomes these deficiencies by using a combination of primers and fluorescent probes specific for a unique DNA sequence. The detection of the target product is followed in real time as the reaction occurs, without the need for agarose gel electrophoresis. Fach et al. (2009), Kimura et al. (2001) and Yoon et al. (2005) used real-time-based assays to target single botulinum toxin genes, whilst Akbulut et al. (2004) and Kasai et al. (2007) targeted multiple BoNT genes in a single real-time reaction. The single-target assays do not completely provide researchers or clinical laboratory technicians with the ability to identify which BoNT gene is present in an isolate. In addition, no assay has been published that involves qPCR detection of the four human disease-causing toxin genes, A, B, E and F, in a single-tube, multiplex reaction.

This report describes the development of a qPCR singletube assay that uniquely identifies the four BoNT types responsible for human disease. A total of 79 C. botulinum isolates was evaluated in this study, as well as numerous near-neighbours and other bacterial species. Included were isolates possessing genes for each of the toxins $\mathrm{A}, \mathrm{B}, \mathrm{E}$ and $\mathrm{F}$, with some wild-type isolates containing genes for more than one BoNT. The results showed that this quadruplex assay was capable of detecting any of these four BoNT genes in a given sample at a sensitivity of as little as $130 \mathrm{fg}$ genomic DNA. Furthermore, it was able to detect the presence of two, three or all four toxin genes in a given sample (even though the existence of a strain producing more than two BoNT types has never been described), indicating the lack of type-to-type interference. The assay was also functional in the presence of extraneous organic matter commonly found in various environmental samples. This assay could prove to be a useful tool in the rapid identification of a specific type of disease, or the potential toxic threat of a substance to human health.

\section{METHODS}

Bacterial isolates and culture conditions. Bacterial isolates (see Supplementary Table S1, available in JMM Online) used in this study were acquired from the American Type Culture Collection (ATCC), CDC and the Utah Department of Health (UDH). Isolates were inoculated on reinforced clostridial agar and grown in an anaerobic chamber at $37{ }^{\circ} \mathrm{C}$ for $3-5$ days prior to DNA extraction.

DNA extraction. Total genomic DNA was extracted from each isolate by first suspending cells grown on reinforced clostridial agar plates in $250 \mu \mathrm{l}$ TE buffer [10 mM Tris/HCl (pH 8.0), 1 mM EDTA] containing $1.8 \mu \mathrm{g}$ lysozyme $\mu^{-1}$ and incubating for $1 \mathrm{~h}$ at $37^{\circ} \mathrm{C}$. This suspension was then processed following the protocol specified in the MagNA Pure LC DNA isolation kit III (Roche Diagnostics). Briefly, $270 \mu \mathrm{l}$ bacterial lysis buffer and $100 \mu \mathrm{l}$ proteinase $\mathrm{K}$ were added and the tube was incubated for $10 \mathrm{~min}$ at $65{ }^{\circ} \mathrm{C}$. Samples were then incubated in boiling water for $10 \mathrm{~min}$, followed by an automated DNA extraction performed using the MagNA Pure LC system and the kit as recommended by the manufacturer. The DNA was diluted with TE buffer in preparation for filtering and stored at $4{ }^{\circ} \mathrm{C}$ overnight, followed by filtration through a $0.2 \mu \mathrm{m}$ centrifuge filter and then testing for sterility. DNA concentrations were measured using a TBS380 fluorometer (Tuner Biosystems) and a P7589 PicoGreen kit (Invitrogen).

Primer and probe design. DNA sequences for isolates from each subtype of the C. botulinum A, B, E and F toxin genes were obtained from GenBank (Table 1). All primers and 5'-hydrolysis dual-labelled probes (Table 2) were designed using the PrimerQuest algorithms from Integrated DNA Technologies (http://www.idtdna.com/Scitools/ Applications/Primerquest/). Primer sequences were selected for suitable $\mathrm{G}+\mathrm{C}$ content, optimal annealing temperatures and lack of hairpin structures. A thorough BLAST search was performed to ensure primer and probe specificity and a lack of similarity with sequences from other organisms and toxins. Probes were fluorescently labelled as follows: toxin A with FAM, toxin B with Cy3, toxin E with Cy5 and toxin $\mathrm{F}$ with Texas Red. Primer and probe sequences were chosen that would allow amplification of all subtypes, with the possible exception of the rare subtype E6.

Optimization of qPCR. Parameter variables such as the number of PCR cycles, cycle temperatures and length of annealing and replicating steps were all optimized. Primers were first evaluated with SYBR Green to optimize cycle temperatures and times. For every two reactions, a master mix of $50 \mu \mathrm{l}$ was prepared using SmartMix HM $50 \mu$ beads and the following: $500 \mathrm{nM}$ forward primer, $500 \mathrm{nM}$ reverse primer, target DNA, $2 \mu$ l SYBR Green at a $25 \times$ concentration and HPLC-grade $\mathrm{H}_{2} \mathrm{O}$ to $50 \mu \mathrm{l}$. The master mix was split equally between two $25 \mu \mathrm{l}$ Cepheid PCR tubes, which were loaded into a SmartCycler II (Cepheid). During the cycling phase, the extension temperatures were varied from 52 to $66{ }^{\circ} \mathrm{C}$ in single-degree increments to maximize the reaction. The optimized protocol identified and used for all singleplex assays was an initial denaturation at $95{ }^{\circ} \mathrm{C}$ for $120 \mathrm{~s}$ followed by 40 cycles of $95{ }^{\circ} \mathrm{C}$ for $15 \mathrm{~s}, 62{ }^{\circ} \mathrm{C}$ for $30 \mathrm{~s}$ and $72{ }^{\circ} \mathrm{C}$ for $20 \mathrm{~s}$.

Quadruplex qPCR assay. Once the single-reaction conditions were optimized, the mixture was quadruplexed by using GE Healthcare Hot Start Mix RTG Master Mix (GE Healthcare). The sample volume was $25 \mu \mathrm{l}$ per reaction, as recommended by the manufacturer. For each reaction, one Master Mix bead was added to a mixture of 
Table 1. GenBank accession numbers of BoNT subtype sequences used for primer development

Strains are C. botulinum unless indicated otherwise.

\begin{tabular}{|c|c|c|c|}
\hline BoNT subtype & Strain & Accession no. & Reference \\
\hline $\mathrm{A} 1$ & ATCC 25763 & EF028391 & Hill et al. (2007) \\
\hline A2 & Kyoto-F & X73423 & Arndt et al. (2006) \\
\hline A3 & Loch Maree & DQ185900 & Arndt et al. (2006) \\
\hline A4 & 657 & DQ185901 & Arndt et al. (2006) \\
\hline A5 & H0 4402065 & EU679004 & Carter et al. (2009) \\
\hline $\mathrm{B}$ bivalent (BvB) & 657 & EF033130 & Smith et al. (2007) \\
\hline B1 & CDC 1758 & EF033127 & Hill et al. (2007) \\
\hline B2 & ATCC 7949 & EF028395 & Hill et al. (2007) \\
\hline B3 & CDC 795 & EF028400 & Hill et al. (2007) \\
\hline B non-proteolytic & ATCC 25765 & X71343 & Hill et al. (2007) \\
\hline E1 & K14 & AM695757 & Chen et al. (2007) \\
\hline E2 & E544 & EF028404 & Chen et al. (2007) \\
\hline E3 & E185 & EF028403 & Chen et al. (2007) \\
\hline E4 & C. butyricum BL 6340 & AB039264 & Chen et al. (2007) \\
\hline E5 & C. butyricum LCL 155 & AB037704 & Chen et al. (2007) \\
\hline E6 & K35 & AM695752 & Chen et al. (2007) \\
\hline $\mathrm{F}$ proteolytic & NCTC 10281 & X81714 & Smith et al. (2005) \\
\hline F non-proteolytic & ATCC 23387 & M92906 & Smith et al. (2005) \\
\hline $\mathrm{F}$ bivalent (BvF) & CDC 3281 & Y13631 & Smith et al. (2005) \\
\hline
\end{tabular}

$250 \mathrm{nM}$ of each primer and probe for toxin A and $500 \mathrm{nM}$ of each primer and probe for toxins $\mathrm{B}, \mathrm{E}$ and $\mathrm{F}$. Target DNA and PCR-grade $\mathrm{H}_{2} \mathrm{O}$ were added for a total reaction volume of $25 \mu$ l. If DNA containing genes from more than two different toxin types was used, two Master Mix beads were used per reaction. Thermal cycling conditions were the same as for the singleplex reactions. SmartCycler program conditions were the same as the program defaults. A sample was determined as positive if it crossed a fluorescence threshold of 15 before cycle $40\left(\mathrm{a} C_{\mathrm{T}}\right.$ value of $<40$ ). The Cepheid software allowed four optics channels to be monitored simultaneously in real time. DNA from near neighbours and no template were used as negative controls. The optimized real-time protocol was evaluated using a collection of 79 C. botulinum isolates, six near neighbours and 11 other common laboratory strains of bacteria (Table 3).

Environmental samples. To ascertain the effectiveness of the assay on environmental samples, $400 \mathrm{mg}$ sausage, $400 \mathrm{mg}$ vegetable matter (Beech Nut Mixed Vegetables Baby Food), $150 \mathrm{mg}$ soil and $150 \mathrm{mg}$

Table 2. Primer and probe sequences

BHQ1, Black Hole Quencher 1; BHQ2, Black Hole Quencher 2; FAM, carboxyfluorescein; IabRQ, Iowa Black Quencher RQ; TexR, Texas Red.

\begin{tabular}{|c|c|c|}
\hline Primer/probe & Sequence $\left(5^{\prime} \rightarrow 3^{\prime}\right)$ & Amplicon size $(b p)$ \\
\hline \multicolumn{3}{|l|}{ Toxin A } \\
\hline Forward & ACGCGAAATGGTTATGGYTCTACTC & 142 \\
\hline Reverse & GTGCTAATGYTACYGCTGGATCTG & \\
\hline Probe & FAM-TGAGGAGTCACTTGAAGTTGATACAAATCC-BHQ1 & \\
\hline \multicolumn{3}{|l|}{ Toxin B } \\
\hline Forward & AGTAATCCAGGAGAAGTGGAGCGA & 136 \\
\hline Reverse & CRAAGCCTTCCCTTGATGCAAA & \\
\hline Probe & Су3-CGCAAATTTAATAATATTTGGACCTGGGCC-IabRQ & \\
\hline \multicolumn{3}{|l|}{ Toxin $\mathrm{E}$} \\
\hline Forward & CACAGAAAGTGCCCGAAGGTGAAA & 136 \\
\hline Reverse & GCTGCTTGCACAGGTTTATTGACA & \\
\hline Probe & Су5-GTCAATCTCACСТCTTCAATTGATACAGCA-BHQ2 & \\
\hline \multicolumn{3}{|l|}{ Toxin $\mathrm{F}$} \\
\hline Forward & GTGGAGGGMATMATAGTAGTACAGA & 155 \\
\hline Reverse & GGCTATCATAAGAGGTSCTYGCTTT & \\
\hline Probe & TexR-AGCTCATGAATTGATACATGCACTGCA-BHQ2 & \\
\hline
\end{tabular}


Table 3. Summary of quadruplex qPCR results

\begin{tabular}{|c|c|c|c|c|c|c|c|c|c|c|}
\hline \multirow[t]{2}{*}{ Species } & \multicolumn{6}{|c|}{$\operatorname{Toxin}(\mathrm{s})$} & \multirow[t]{2}{*}{ No toxin } & \multirow{2}{*}{$\begin{array}{c}\text { Purported C } \\
\text { isolates }\end{array}$} & \multirow{2}{*}{$\begin{array}{l}\text { Purported } \\
\text { D isolates }\end{array}$} & \multirow[t]{2}{*}{ Total } \\
\hline & A & B & $\mathbf{E}$ & F & $A$ and $B$ & $B$ and $F$ & & & & \\
\hline C. botulinum & 36 & 14 & 3 & 4 & 7 & 2 & 1 & 9 & 3 & 79 \\
\hline C. argentinense & 0 & 0 & 0 & 0 & - & - & & - & - & 2 \\
\hline C. beijerinckii & 0 & 0 & 0 & 0 & - & - & & - & - & 1 \\
\hline C. haemolyticum & 0 & 0 & 0 & 0 & - & - & & - & - & 1 \\
\hline C. perfringens & 0 & 0 & 0 & 0 & - & - & & - & - & 1 \\
\hline C. subterminale & 0 & 0 & 0 & 0 & - & - & & - & - & 1 \\
\hline Other species & 0 & 0 & 0 & 0 & - & - & & - & - & 11 \\
\hline
\end{tabular}

human faeces were inoculated individually with $100 \mu$ concentrated (about $10^{8}$ c.f.u. $\mathrm{ml}^{-1}$ ) cultures of C. botulinum isolates known to contain the A, B, E and F toxin genes. Phase microscopy showed these cultures to be about $60 \%$ spores and $40 \%$ vegetative cells. For negative controls, concentrated cultures of individual isolates containing the $\mathrm{C}$ or $\mathrm{D}$ toxin genes or $100 \mu \mathrm{TE}$ buffer (no bacteria) were used. After inoculation, the suspensions underwent bead-beating for $5 \mathrm{~min}$ at the maximum setting in a Mini BeadBeater-8 (BioSpec Products), followed by incubation for $30 \mathrm{~min}$ at $37^{\circ} \mathrm{C}$. Samples were centrifuged for $5 \mathrm{~min}$ at $5220 \mathrm{~g}$. The supernatant was removed and $270 \mu \mathrm{l}$ bacterial lysis buffer and $100 \mu \mathrm{l}$ proteinase K were added as described above, followed by incubation at $65{ }^{\circ} \mathrm{C}$ for $10 \mathrm{~min}$. Samples were then incubated in boiling water for $10 \mathrm{~min}$, followed by DNA extraction and dilution as described above. The extracted DNA was then analysed using the quadruplex assay.

Validation of the quadruplex assay. To verify the validity of the assay and ensure the correct identification of some isolates, an adapted version of the assay developed by Lindström et al. (2001) was used. The primer sequences employed were identical to those reported by Lindström et al. (2001). The primer sets were used as singleplex reactions by mixing one Master Mix bead, $500 \mathrm{nM}$ of each of the forward and reverse primers, $1.25 \mu \mathrm{l} 20 \times$ SYBR Green, target DNA and PCR-grade $\mathrm{H}_{2} \mathrm{O}$ to $25 \mu \mathrm{l}$. The reactions were then run in the SmartCycler II with the following cycling conditions: $95{ }^{\circ} \mathrm{C}$ for 2 min followed by 35 cycles of $95{ }^{\circ} \mathrm{C}$ for $25 \mathrm{~s}, 60{ }^{\circ} \mathrm{C}$ for $25 \mathrm{~s}$ and $72{ }^{\circ} \mathrm{C}$ for $60 \mathrm{~s}$.

The singleplex assays by Fach et al. (2009) were also employed to further confirm the validity of the assay. All primer and probe sequences used were exactly as reported by Fach et al. (2009), as were the cycling conditions. All assays were performed on a Cepheid SmartCycler II.

Mouse bioassay. Much of the mouse bioassay information was gathered from sources at ATCC, CDC and UDH. The information that could not be obtained from these sources was generated by performing the mouse bioassay on those isolates. Briefly, C. botulinum cultures were grown in chopped meat medium (Anaerobe Systems) for 7 days. The liquid portion of the broth was removed to an Oakridge tube. An equal amount of cold gelatin diluent was added to the tube and vortexed. The tube was centrifuged at $15000 \mathrm{~g}$ for $20 \mathrm{~min}$ at $4{ }^{\circ} \mathrm{C}$. The supernatant was removed and placed in a sterile screw-capped tube. Aliquots of $1 \mathrm{ml}$ of this solution were placed in separate tubes for toxin neutralization assays, which involved the addition of $0.25 \mathrm{ml}$ antitoxin to neurotoxin types A, B, E or $\mathrm{ABE}$ antitoxin. One aliquot was left untreated. These mixtures of extract and antiserum were incubated at room temperature for 30 $60 \mathrm{~min}$. In addition, one aliquot was tested for heat lability. An aliquot of specimen was prepared for heat lability testing by placing approximately $1.2 \mathrm{ml}$ of the extract in a sterile screw-capped tube that was loosely capped. The tube was then heated in a boiling water bath for $10 \mathrm{~min}$ and allowed to return to room temperature.

Mice weighing $20 \mathrm{~g}$ each were inoculated intraperitoneally with $0.5 \mathrm{ml}$ extract and observed for signs of botulism at 4, 8, 12, 24, 48, 72 and $96 \mathrm{~h}$ post-injection. Botulinum toxin was considered to be present if samples of the raw extract caused symptoms of botulism followed by death when injected into mice, but did not cause symptoms of botulism or death when heated or mixed with one of the monovalent or trivalent antitoxins specific for the botulinum toxin involved.

\section{RESULTS AND DISCUSSION}

C. botulinum strains are not as homogeneous as many other bacterial species; they have marked genotypic heterogeneity and express varied phenotypic characteristics such as optimal growth temperatures (ranging from 18 to $40{ }^{\circ} \mathrm{C}$ ), biochemical profiles and metabolite production. There are also non-BoNT-producing strains that are so closely related that they can be identified genetically and biochemically as members of each C. botulinum group (Collins \& East, 1998; Hatheway, 1990; Lindström et al., 2001) but are given different species names because they produce no toxin. The main commonality between all $C$. botulinum strains is the production of one or more of the seven antigenically distinct BoNTs A-G (Collins \& East, 1998; Hatheway, 1990; Lindström et al., 2001). C. botulinum strains can be divided into four groups (I-IV) depending on which toxin type(s) the organism produces, with groups I and II being the primary cause of disease in humans. Group I consists of any strain producing one or more of toxin type A and the proteolytic types B and F. Group II comprises any strain producing one or more of toxin type $\mathrm{E}$ and the non-proteolytic types B and F. Group III organisms produce toxin types C and D (Collins \& East, 1998; Lindström et al., 2001; Smith \& Sugiyama, 1988), which often cause botulism in birds and cattle (Heffron \& Poxton, 2007; Prévot et al., 2007). Group IV organisms produce toxin type G (Collins \& East, 1998; Smith \& Sugiyama, 1988), which has not been shown to produce disease in animals or humans (Yoon et al., 2005). C. botulinum isolates that produce the $\mathrm{G}$ toxin are classified 
by some as a separate species, Clostridium argentinense (Suen et al., 1988).

Whilst most C. botulinum strains produce a single BoNT, some isolates have been identified that produce a mixture of two toxin types: A and F (Giménez \& Ciccarelli, 1970), A and B (Córdoba et al., 1995; Poumeyrol et al., 1983) and B and F (Barash \& Arnon, 2004; Hatheway \& McCroskey, 1989). Some type A isolates have been found to harbour silent type B BoNT genes (Córdoba et al., 1995; Franciosa et al., 1994). When multiple toxin genes are present, the primary toxin produced is usually dependent on growth temperature (Barash \& Arnon, 2004).

Many different assays and detection protocols have been used to identify BoNT in various substances, including food, animal tissue and faecal samples (Dietmaier \& Hofstadter, 2001; Franz et al., 1997; Lyon, 2001). In our novel qPCR assay, all of the primers, probes and target DNA were loaded into a single tube. Each individual duallabelled hydrolysis probe had a unique fluorescence signal that was detected and analysed by the specific detection channels of the SmartCycler II. Additionally, each primer was specific for DNA sequences corresponding to a particular toxin type. Collectively, these components comprise a highly sensitive assay capable of specifically detecting the genes for all four toxin types within a single PCR tube.

\section{Specificity testing}

The initial specificity of each primer was evaluated in separate qPCR tubes using SYBR Green to detect amplification. Specific primers yielded threshold amplification in the presence of DNA for their respective toxin types, whilst maintaining a steady non-amplification state when any other DNA was added. Having established that the primers were highly specific to their respective DNA targets, the SYBR Green was replaced with specific duallabelled hydrolysis probes for toxin types A, B, E and F. All isolates were tested a minimum of three times, and signal thresholds were exceeded only when specific primer and probe sets were used on target DNAs containing the corresponding toxin gene, indicating target specificity. When DNA from two, three or four toxin types was combined, each toxin type produced a positive threshold signal. C. botulinum isolates containing the $\mathrm{C}$ or D toxin genes and near neighbours consistently produced a negative response in all dye channels (Fig. 1).

Of the 96 isolates examined in this study (Supplementary Table S1), 79 were C. botulinum and tested positive for sequences corresponding to their respective toxin types (A, B, E or F). A total of 13 C. botulinum isolates producing the toxins $\mathrm{C}$ and $\mathrm{D}$, which do not cause disease in humans, were also included as controls and always produced a negative result for the assay. Six clostridial near-neighbour species tested negative for all four toxin types (Table 3). (a)

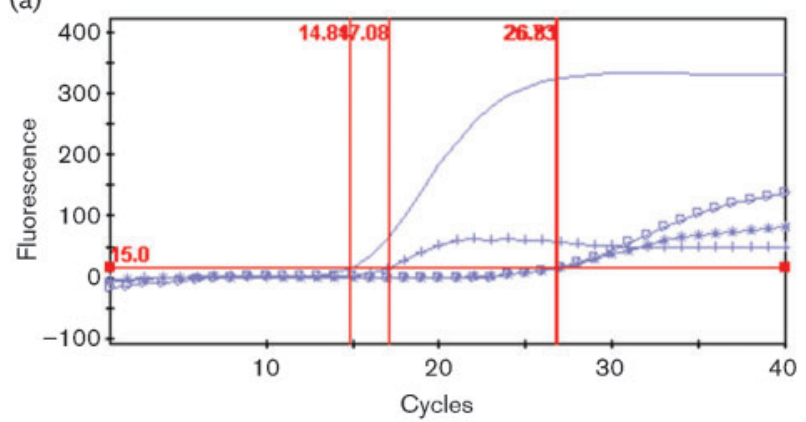

(b)

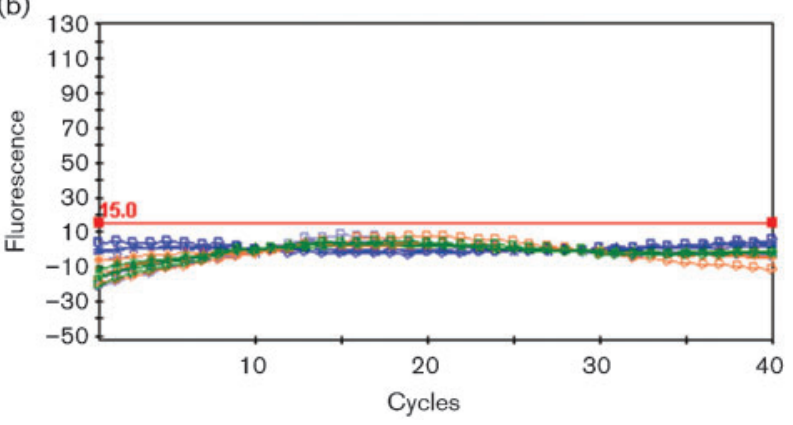

Fig. 1. Simultaneous detection of toxins $A, B, E$ and $F$. (a) The quadruplex assay detected all four toxins concurrently. -, Toxin $A$; + , toxin $B$; $\bigcirc$, toxin $E ;{ }^{*}$, toxin $F$. (b) Toxin types $C$ (blue line) and D (orange line) and near-neighbours (C. argentinense, green line; $C$. perfringens, grey line) produced negative results. $C_{\mathrm{T}}$ values are expressed as vertical red lines and the threshold is expressed as a horizontal red line.

\section{Sensitivity testing}

For each isolate, tenfold serial dilutions were made of the purified genomic DNAs. For the singleplex assays, the threshold sensitivities for each toxin type were at least $13 \mathrm{fg}$ for type A, $7.0 \mathrm{fg}$ for type B, $8.4 \mathrm{fg}$ for type $\mathrm{E}$ and $8.4 \mathrm{fg}$ for type F (Fig. 2). For the quadruplex assay, the threshold sensitivities for each toxin type were at least 130 fg for type A, $700 \mathrm{fg}$ for type B, $840 \mathrm{fg}$ for type $\mathrm{E}$ and 840 fg for type $\mathrm{F}$ (Fig. 3). This corresponded to a sensitivity of about $1-2$ genome copies for the singleplex assays and 15-100 genome copies for the quadruplex assay depending on toxin type.

\section{Toxin type variance from the purported type}

The isolates tested using the described assay represented a wide diversity, with multiple isolates representing each of the toxin types A-F. In most cases (59/72 isolates containing $\mathrm{A}, \mathrm{B}, \mathrm{E}$ or $\mathrm{F}$ toxin genes), the purported toxin type exactly matched that identified by the described assay. For seven isolates (CDC isolates $10305 \mathrm{~T}-5,10306 \mathrm{~A}-2$ and 10360 A-1 and UDH isolates 70200855, 70300379, 70401029 and 79002066), the mouse bioassay detected only the A toxin, whereas our assay detected the presence of both A and B toxin genes (Supplementary Table S1). 
(a)
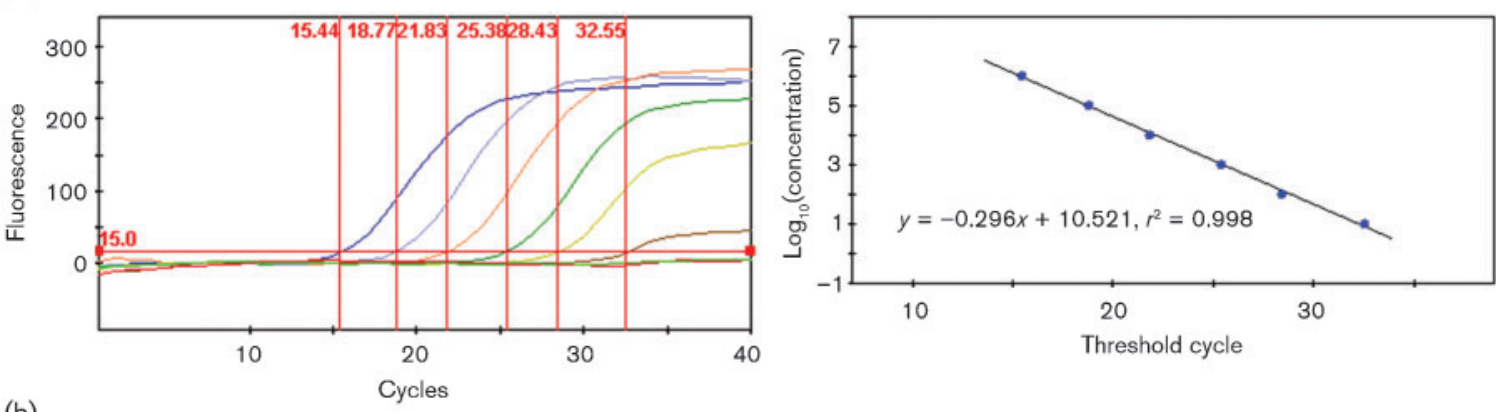

(b)
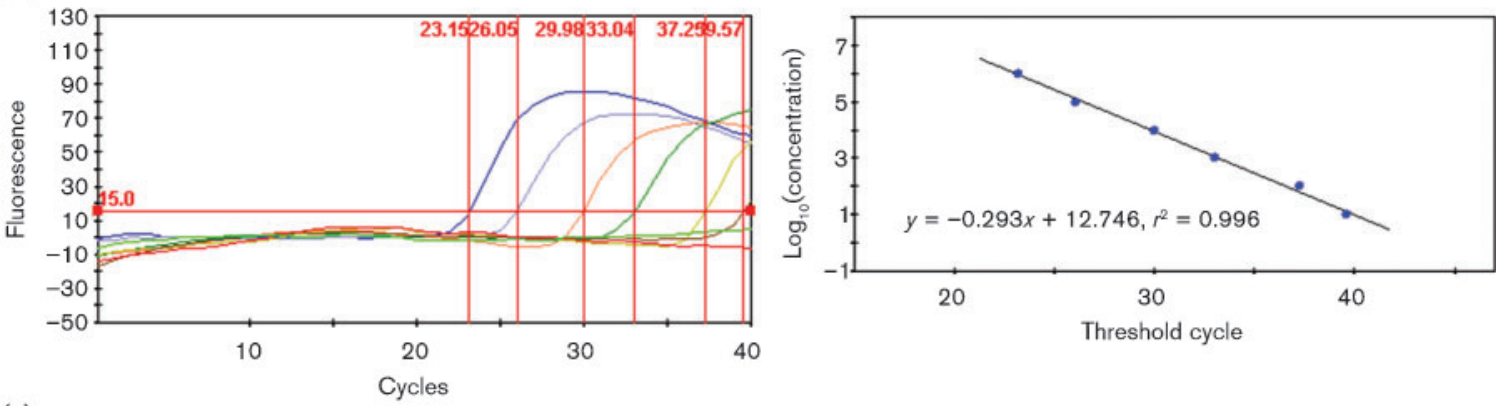

(c)
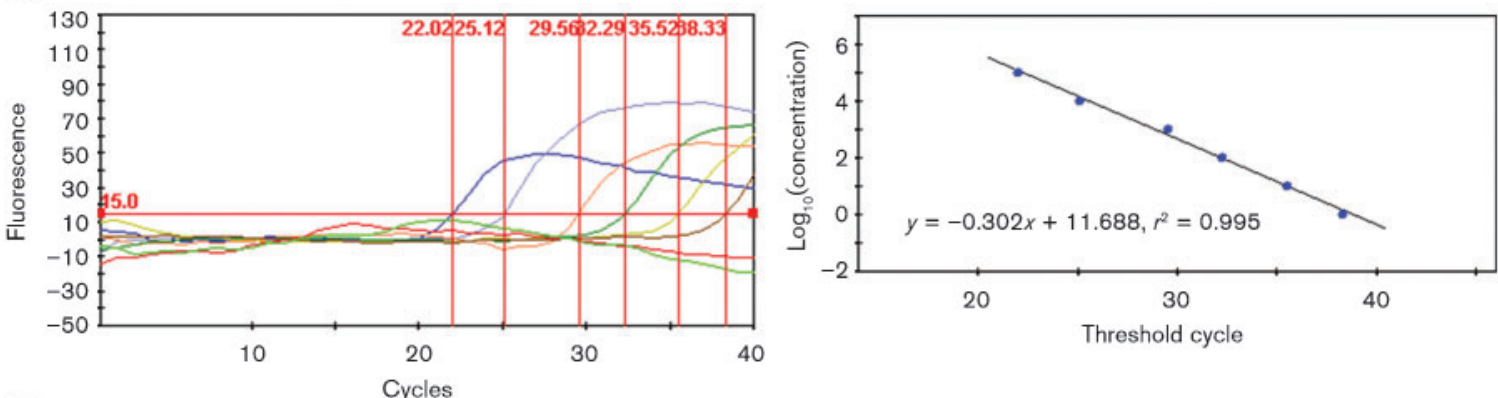

(d)
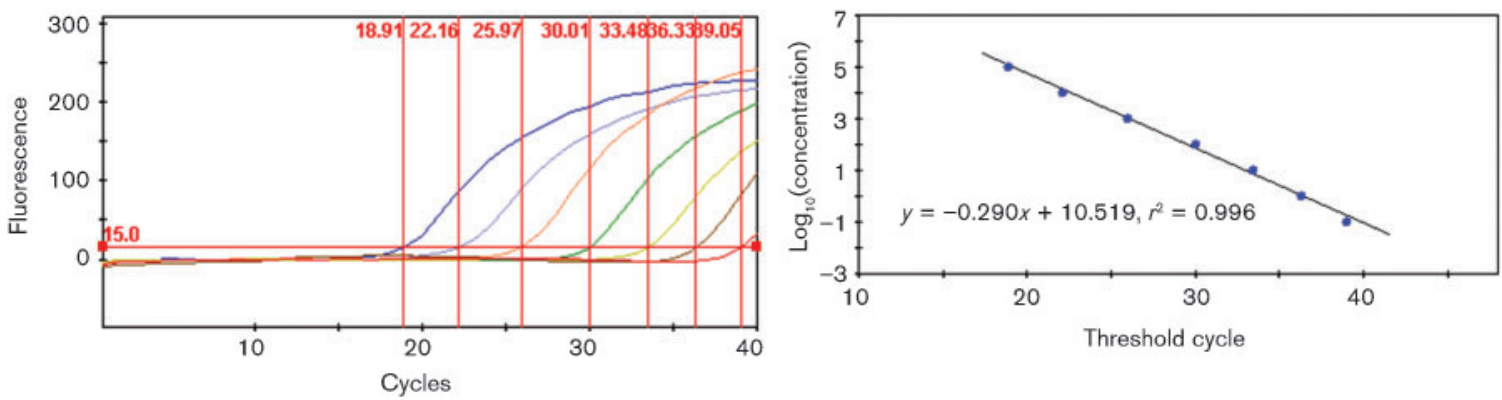

Fig. 2. Sensitivity of the singleplex assays. Standard curves derived from tenfold dilutions of purified genomic DNAs for $C$. botulinum isolates containing the toxin genes for toxin A (a), toxin B (b), toxin $E(c)$ and toxin $F(d)$.

The presence of genes for more than one toxin type with only one type being expressed has been reported previously (Córdoba et al., 1995; Poumeyrol et al., 1983). This is likely to be the case for these isolates. There were also three isolates for which our assay results varied from the purported toxin type. The ATCC isolates 438 and 17786 were purported to produce toxin types $\mathrm{B}$ and $\mathrm{E}$, respectively, but our assay detected the gene for toxin type A in both isolates. Mouse bioassay data on these cultures confirmed toxin type A for both of these isolates. The ATCC isolate 17845 was purported to have the B toxin gene, but no toxin genes were identified. This result was also confirmed by the mouse bioassay. It is possible that the toxin gene was contained on a plasmid that was lost during repeated culture. 
(a)

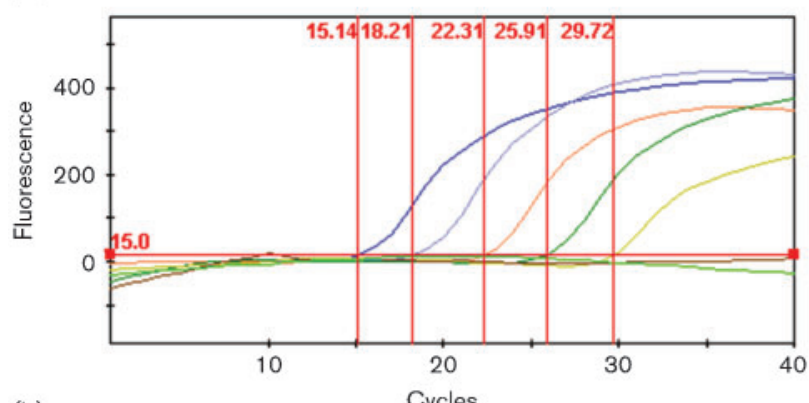

(b)

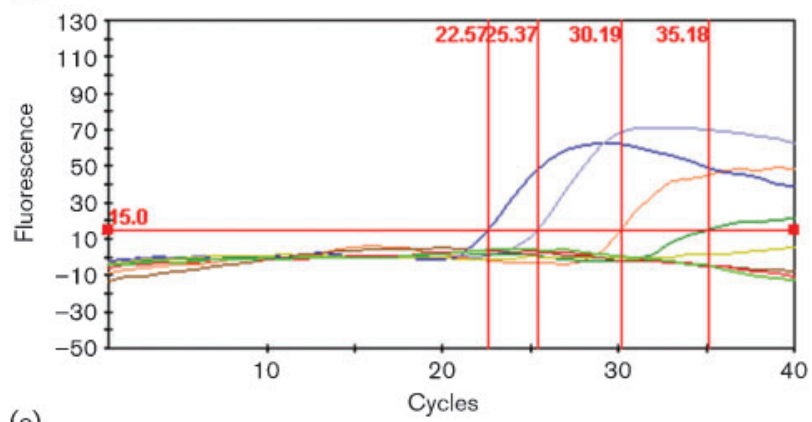

(c)

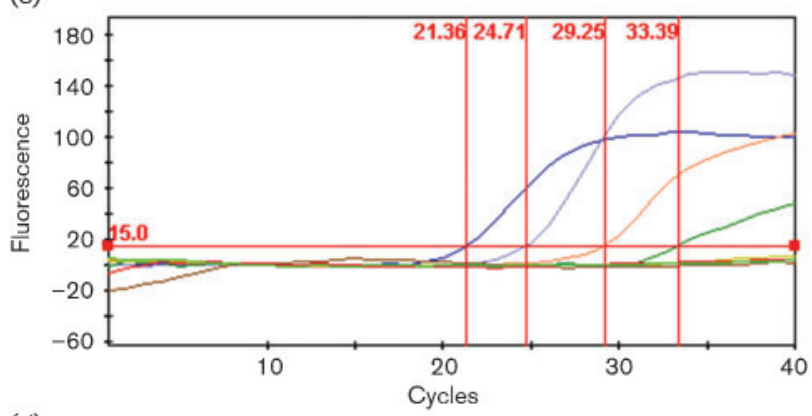

(d)

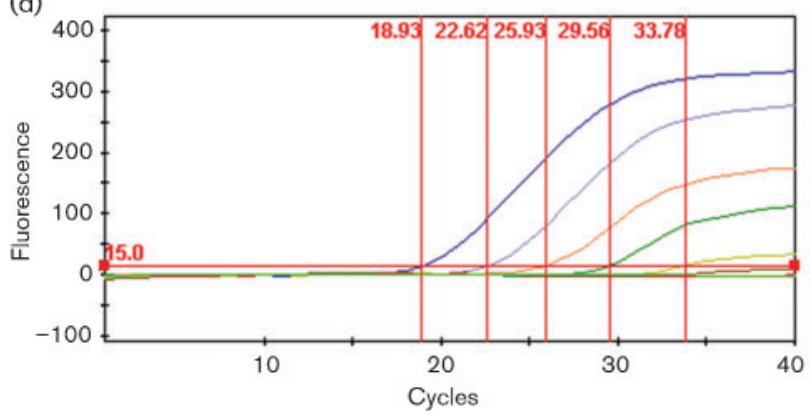

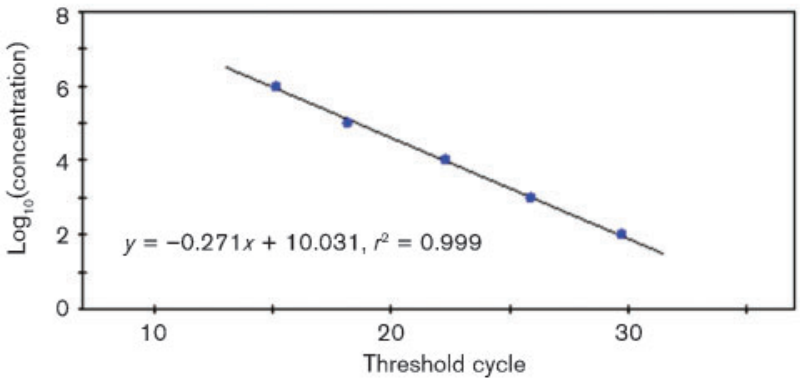
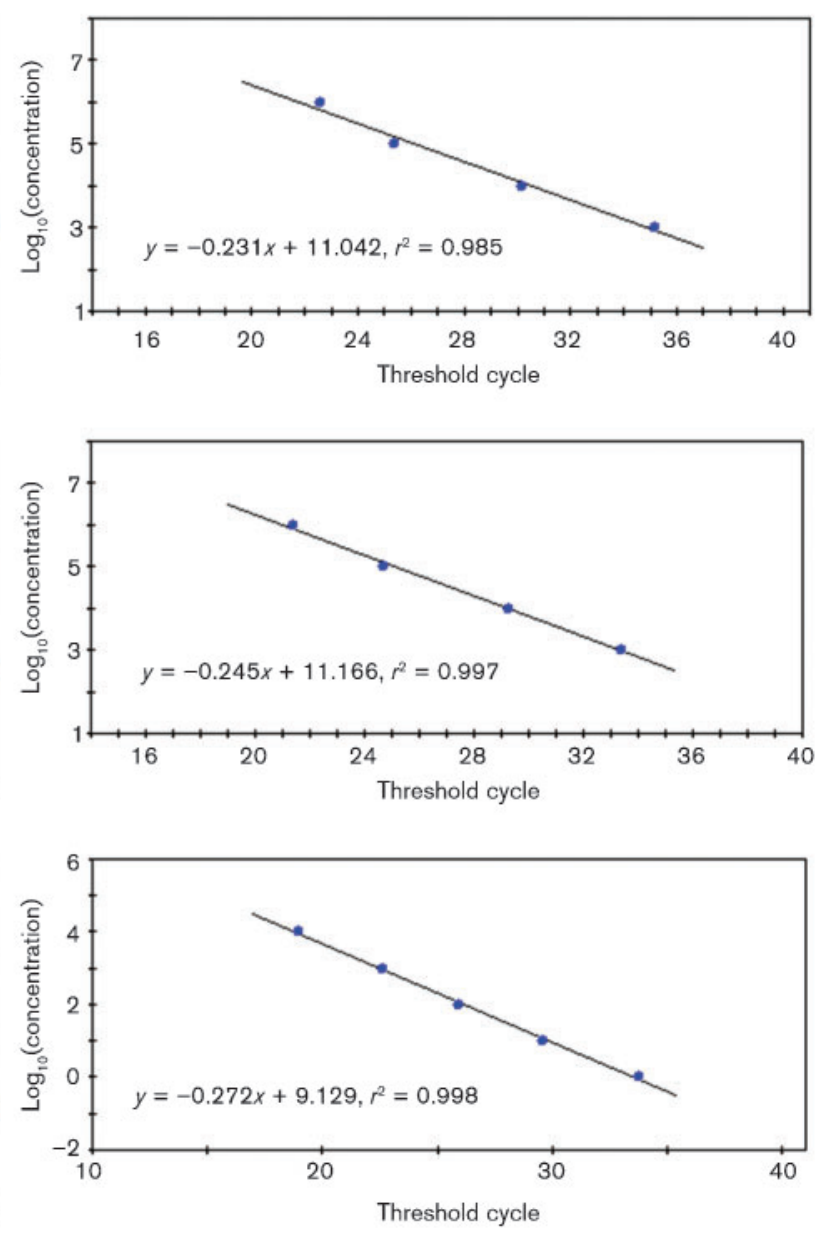

Fig. 3. Sensitivity of the quadruplex assay. Standard curves derived from tenfold dilutions of purified genomic DNAs for $C$. botulinum isolates containing the toxin genes for toxin $A(a)$, toxin $B(b)$, toxin $E(c)$ and toxin $F(d)$.

\section{Confirmation of the quadruplex assay}

Several previously published assays were run on these isolates in order to confirm the results obtained by our qPCR assay. The qPCR assay described by Song et al. (2004) was used initially to confirm that all of the isolates were members of the genus Clostridium. The assay described by Lindström et al. (2001) was adapted to a real-time format and all isolates were also retested with this assay. The results indicated that, in every case, the described quadruplex assay detected the BoNT genes correctly. To further confirm the accuracy of the quadruplex assay, a real-time assay recently published by Fach et al. (2009) was used to determine the presence of single toxin genes. These results also matched perfectly with those of our described quadruplex assay. Mouse 
bioassay information was gathered or produced for all isolates, as described above. In addition, fatty acid analysis (MIDI) identified all isolates as C. botulinum.

\section{Environmental samples}

To examine the utility of this assay in investigating environmental samples or samples likely to be encountered in a natural disease outbreak, soil, vegetable material, sausage and faecal material were each inoculated with $C$. botulinum cultures. DNA extracted from each environmental sample was analysed with the quadruplex assay. It was found that the assay could differentiate between toxin types in the vegetable matter and the sausage, with the negative controls (uninoculated and those inoculated with isolates producing toxin types $\mathrm{C}$ or $\mathrm{D}$ ) showing no signal. Soil often contains a high concentration of PCR inhibitors, but, despite this, all four toxin types were correctly identified in the soil samples (Fig. 4). None of the faecal samples gave a positive signal. In an attempt to determine whether this was due to PCR inhibitors in the extracted samples or whether the DNA extraction process itself was inhibited, a small quantity of DNA was added to the extracted samples $\left(1 \mu \mathrm{l}\right.$ DNA at $10 \mathrm{ng} \mu^{-1}$ into $49 \mu \mathrm{l}$ of each extracted sample). This yielded positive results for every toxin type (Fig. 5), indicating that PCR inhibitors were not interfering with the reaction, but rather that $C$. botulinum DNA was not being liberated from the inoculated bacteria during the extraction process when faecal material was present.
It is important to note that this assay detects DNA sequences that code for four botulinum toxin types. It does not detect the presence of the toxin polypeptides themselves. This would generally not be a problem in a natural disease outbreak situation where organisms would probably be present with their toxin products. However, these DNA sequences may not be present in detectable amounts in highly purified toxin preparations such as those prepared for use as biological weapons.

Previous studies have described how certain strains of $C$. botulinum have the ability to produce two toxin types. Alternatively, an isolate may possess two types of toxin gene, but only one toxin type will be expressed. As this assay detects toxin gene sequences only, these organisms would probably produce positive results for both DNA sequences. Consequently, this assay correctly detects the capacity of $C$. botulinum to produce a specific toxin type.

In summary, this paper describes the creation and validation of a quadruplex qPCR assay that can detect all human disease-causing BoNTs, even when all four are present in the same sample. The quadruplex assay can detect as few as 15-100 genome copies depending on the toxin type, and is robust enough to function in the presence of extracted organic material and soil. This assay could prove to be a rapid, sensitive and economical tool in the detection of BoNT-producing organisms present in a wide variety of samples, and could provide researchers and clinicians with a rapid and reliable means of determining BoNT type. (a)

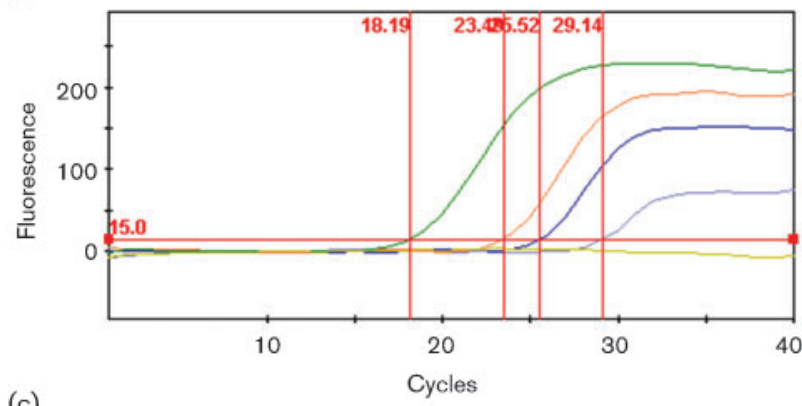

(c)

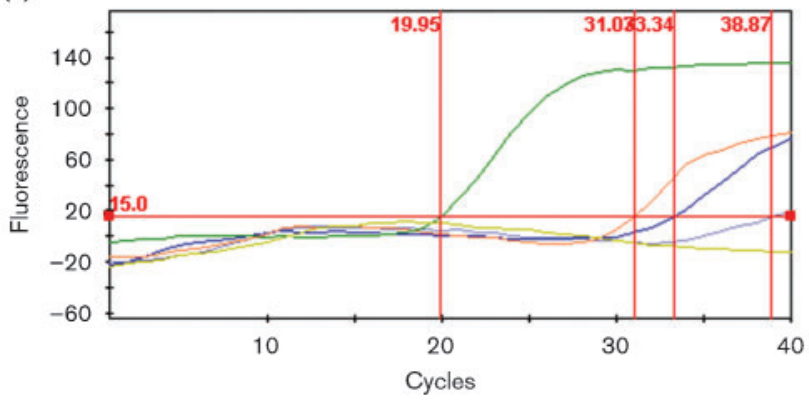

(b)

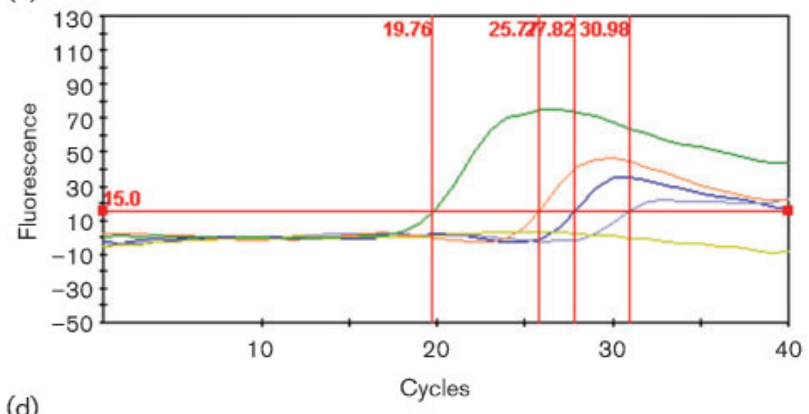

(d)

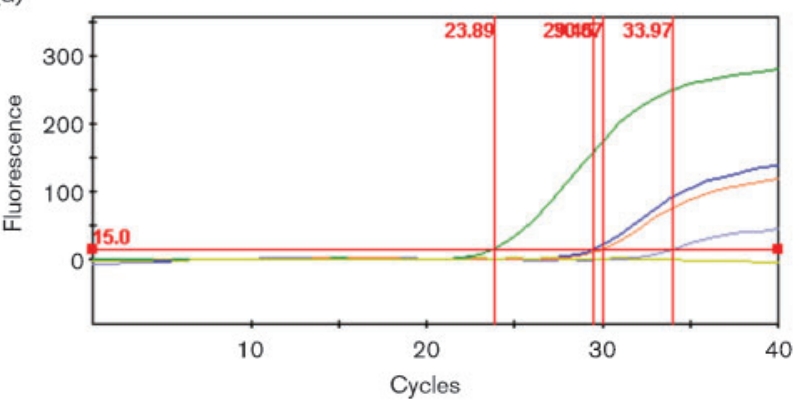

Fig. 4. Detection of the presence of toxin genes in environmental samples. Detection of toxin $A(a)$, toxin $B(b)$, toxin $E$ (c) and toxin $F(d)$ after DNA was extracted from environmental samples inoculated with $C$. botulinum. Samples tested included genomic DNA control (green), sausage (orange), vegetable matter (blue), soil (grey) and a no-template control (yellow). 

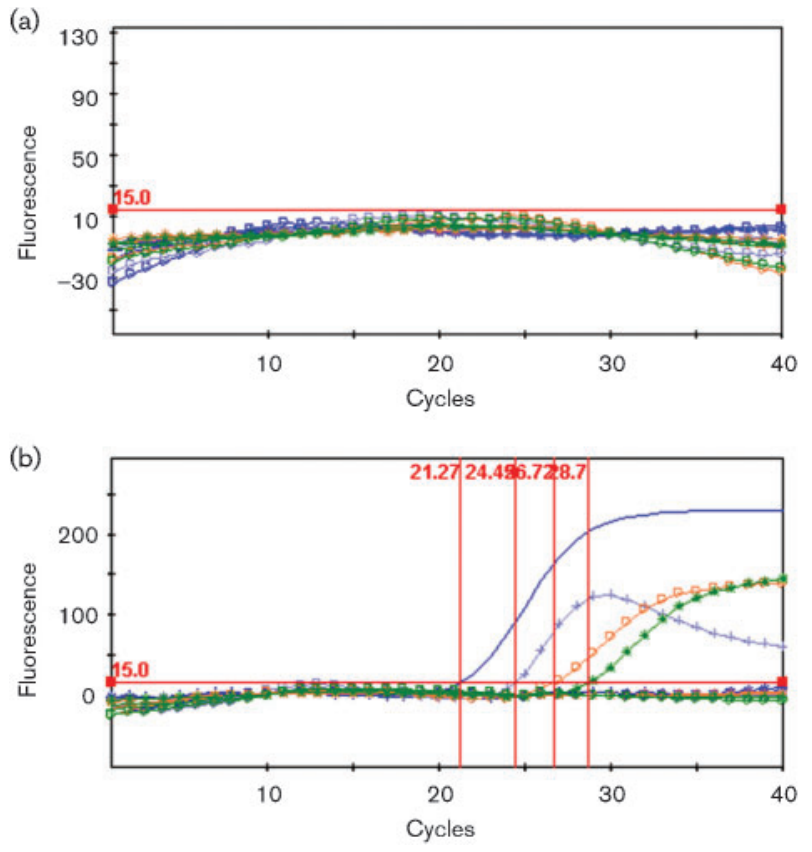

Fig. 5. Detection of the presence of toxin genes in faecal samples. (a) Detection of toxin $A(-)$, toxin $B(+)$, toxin $E(\bigcirc)$, and toxin $F\left(^{*}\right)$ after DNA was extracted from faecal samples inoculated with $C$. botulinum. (b) The same as (a) except that purified DNA of the respective toxin type was spiked into each faecal extraction sample.

\section{ACKNOWLEDGEMENTS}

We are indebted to Dan Andrews and Lori Smith at the Utah Public Health Laboratories for their excellent work with the mouse bioassays. This work was supported by grants from the National Biodefence Analysis and Countermeasures Center (NBACC) and the Brigham Young University Mentoring Environment Grant (MEG) programme.

\section{REFERENCES}

Akbulut, D., Grant, K. A. \& McLauchlin, J. (2004). Development and application of real-time PCR assays to detect fragments of the Clostridium botulinum types A, B, and E neurotoxin genes for investigation of human foodborne and infant botulism. Foodborne Pathog Dis 1, 247-257.

Aranda, E., Rodríguez, M., Asensio, M. \& Córdoba, J. (1997). Detection of Clostridium botulinum types A, B, E and F in foods by PCR and DNA probe. Lett Appl Microbiol 25, 186-190.

Arndt, J. W., Jacobson, M. J., Abola, E. E., Forsyth, C. M., Tepp, W. H., Marks, J. D., Johnson, E. A. \& Stevens, R. C. (2006). A structural perspective of the sequence variability within botulinum neurotoxin subtypes A1-A4. J Mol Biol 362, 733-742.

Barash, J. R. \& Arnon, S. S. (2004). Dual toxin-producing strain of Clostridium botulinum type BF isolated from a California patient with infant botulism. J Clin Microbiol 42, 1713-1715.

Bartram, U. \& Singer, D. (2004). Infant botulism and sudden infant death syndrome. Klin Padiatr 216, 26-30 (in German).
Braconnier, A., Broussolle, V., Nguyen-The, C. \& Carlin, F. (2001). Screening for Clostridium botulinum type A, B, and E in cooked chilled foods containing vegetables and raw material using polymerase chain reaction and molecular probes. J Food Prot 64, 201-207.

Carter, A. T., Paul, C. J., Mason, D. R., Twine, S. M., Alston, M. J., Logan, S. M., Austin, J. W. \& Peck, M. W. (2009). Independent evolution of neurotoxin and flagellar genetic loci in proteolytic Clostridium botulinum. BMC Genomics 10, 115.

Chen, Y., Korkeala, H., Aarnikunnas, J. \& Lindström, M. (2007). Sequencing the botulinum neurotoxin gene and related genes in Clostridium botulinum type E strains reveals orf $x 3$ and a novel type E neurotoxin subtype. J Bacteriol 189, 8643-8650.

Collins, M. D. \& East, A. K. (1998). Phylogeny and taxonomy of the food-borne pathogen Clostridium botulinum and its neurotoxins. J Appl Microbiol 84, 5-17.

Córdoba, J. J., Collins, M. D. \& East, A. K. (1995). Studies on the genes encoding botulinum neurotoxin type A of C. botulinum from a variety of sources. Syst Appl Microbiol 18, 13-22.

Dietmaier, W. \& Hofstadter, F. (2001). Detection of microsatellite instability by real time PCR and hybridization probe melting point analysis. Lab Invest 81, 1453-1456.

Fach, P., Hauser, D., Guillou, J. P. \& Popoff, M. R. (1993). Polymerase chain reaction for the rapid identification of Clostridium botulinum type A strains and detection in food samples. J Appl Bacteriol 75, 234239.

Fach, P., Gibert, M., Griffais, R., Guillou, J. P. \& Popoff, M. R. (1995). PCR and gene probe identification of botulinum neurotoxin A-, B-, E-, F-, and G-producing Clostridium spp. and evaluation in food samples. Appl Environ Microbiol 61, 389-392.

Fach, P., Perelle, S., Dilasser, F., Grout, J., Dargaignaratz, C., Botella, L., Gourreau, J. M., Carlin, F., Popoff, M. R. \& Broussolle, V. (2002). Detection by PCR-enzyme-linked immunosorbent assay of Clostridium botulinum in fish and environmental samples from a coastal area in northern France. Appl Environ Microbiol 68, 58705876.

Fach, P., Micheau, P., Mazuet, C., Perelle, S. \& Popoff, M. (2009). Development of real-time PCR tests for detecting botulinum neurotoxins A, B, E, F producing Clostridium botulinum, Clostridium baratii and Clostridium butyricum. J Appl Microbiol 107, 465-473.

Franciosa, G., Ferreira, J. L. \& Hatheway, C. L. (1994). Detection of type A, B, and E botulism neurotoxin genes in Clostridium botulinum and other Clostridium species by PCR: evidence of unexpressed type B toxin genes in type A toxigenic organisms. J Clin Microbiol 32, 19111917.

Franz, D. R., Jahrling, P. B., Friedlander, A. M., McClain, D. J., Hoover, D. L., Bryne, W. R., Pavlin, J. A., Christopher, G. W. \& Eitzen, E. M. (1997). Clinical recognition and management of patients exposed to biological warfare agents. JAMA 278, 399-411.

Giménez, D. F. \& Ciccarelli, A. S. (1970). Another type of Clostridium botulinum. Zentralbl Bakteriol Orig 215, 221-224.

Hatheway, C. L. (1990). Toxigenic clostridia. Clin Microbiol Rev 3, 66-98.

Hatheway, C. L. \& McCroskey, L. M. (1989). Unusual neurotoxigenic clostridia recovered from human fecal specimens in the investigation of botulism. In Proceedings of the 5th International Symposium on Microbial Ecology: Recent Advances in Microbial Ecology, pp. 477-481. Edited by T. Hattori, Y. Ishida, Y. Maruyama, R. Y. Morita \& A. Uchida. Tokyo: Scientific Societies Press.

Heffron, A. \& Poxton, I. (2007). A PCR approach to determine the distribution of toxin genes in closely related Clostridium species: Clostridium botulinum type C and D neurotoxins and C2 toxin, and Clostridium novyi a toxin. J Med Microbiol 56, 196-201. 
Hill, K. K., Smith, T. J., Helma, C. H., Ticknor, L. O., Foley, B. T., Svensson, R. T., Brown, J. L., Johnson, E. A., Smith, L. A. \& other authors (2007). Genetic diversity among botulinum neurotoxinproducing Clostridial strains. J Bacteriol 189, 818-832.

Kasai, Y., Kimura, B., Tarima, Y. \& Fujii, T. (2007). Quantitative duplex PCR of Clostridium botulinum types A and B neurotoxin genes. Shokuhin Eiseigaku Zasshi 48, 19-26.

Kimura, B., Kawasaki, S., Nakano, H. \& Fujii, T. (2001). Rapid, quantitative PCR monitoring of growth of Clostridium botulinum type E in modified-atmosphere-packaged fish. Appl Environ Microbiol 67, 206-216.

Lindström, M. K., Jankola, H. M., Hielm, S., Hyytiä, E. K. \& Korkeala, H. J (1999). Identification of Clostridium botulinum with API 20 A, Rapid ID 32 A and RapID ANA II. FEMS Immunol Med Microbiol 24, 267-274.

Lindström, M., Keto, R., Markkula, A., Nevas, M., Hielm, S. \& Korkeala, H. (2001). Multiplex PCR assay for detection and identification of Clostridium botulinum types A, B, E, and F in food and fecal material. Appl Environ Microbiol 67, 5694-5699.

Lyon, E. (2001). Mutation detection using fluorescent hybridization probes and melting curve analysis. Expert Rev Mol Diagn 1, 92-101.

Poumeyrol, M., Billon, J., Delille, F., Haas, C., Marmonier, A. \& Sebald, M. (1983). Fatal case of botulism due to a type $A B$ Clostridium botulinum strain. Med Mal Infect 13, 750-754 (in French).

Prévot, V., Tweepenninckx, F., Van Nerom, E., Linden, A., Content, J. \& Kimpe, A. (2007). Optimization of polymerase chain reaction for detection of Clostridium botulinum type C and D in bovine samples. Zoonoses Public Health 54, 320-327.

Smith, L. de S. \& Sugiyama, H. (1988). Botulism: the Organism, its Toxins, the Disease, 2nd edn. Springfield, IL: Charles C. Thomas.
Smith, T. J., Lou, I. N., Geren, C. M., Forsyth, R., Tsai, S. L., LaPorte, W. H., Tepp, M., Bradshaw, E. A., Johnson, L. A. \& other authors (2005). Sequence variation within botulinum neurotoxin serotypes impacts antibody binding and neutralization. Infect Immun 73, 5450-5457.

Smith, T. J., Hill, K. K., Foley, B. T., Detter, J. C., Munk, A. C., Bruce, D. C., Doggett, N. A., Smith, L. A., Marks, J. D. \& other authors (2007). Analysis of the neurotoxin complex genes in Clostridium botulinum A1A4 and B1 strains: BoNT/A3, /Ba4 and /B1 clusters are located within plasmids. PLoS One 2, e1271.

Song, Y., Liu, C. \& Finegold, S. M. (2004). Real-time PCR quantitation of clostridia in feces of autistic children. Appl Environ Microbiol 70, 6459-6465.

Suen, J. C., Hatheway, C. L., Steigerwalt, A. G. \& Brenner, D. J. (1988). Clostridium argentinense sp. nov.: a genetically homogeneous group composed of all strains of Clostridium botulinum type $\mathrm{G}$ and some nontoxigenic strains previously identified as Clostridium subterminale or Clostridium hastiforme. Int J Syst Bacteriol 38, 375381.

Szabo, E. A., Pemberton, J. M. \& Desmarchelier, P. M. (1993). Detection of the genes encoding botulinum neurotoxin types A to E by the polymerase chain reaction. Appl Environ Microbiol 59, 30113020.

Takeshi, K., Fujinaga, Y., Inoue, K., Nakajima, H., Oguma, K., Ueno, T., Sunagawa, H. \& Ohyama, T. (1996). Simple method for detection of Clostridium botulinum type A to $\mathrm{F}$ neurotoxin genes by polymerase chain reaction. Microbiol Immunol 40, 5-11.

Yoon, S. Y., Chung, G. T., Kang, D. H., Ryu, C., Yoo, C. K. \& Seong, W. K. (2005). Application of real-time PCR for quantitative detection of Clostridium botulinum type A toxin gene in food. Microbiol Immunol 49, 505-511. 